\title{
EXAMINATION OF THE EFFECTS OF THE CROPYEAR AND THE NUTRIENT SUPPLY ON THE QUALITY OF WINTER WHEAT WITH THE HELP OF GYÖRI'S Z-INDEX
}

\author{
Éva Szabó \\ Institute of Crop Science, Faculty of Agricultural and Food Sciences and Environmental Management, Centre for Agricultural and Applied \\ Economic Sciences, University of Debrecen, H-4032 Debrecen Böszörményi str. 138., e-mail: szaboeva @ agr.unideb.hu
}

\author{
Keywords: winter wheat, fertilization, cropyear, baking quality, Győri’s z-index
}

\begin{abstract}
Summary
In the case of winter wheat, the knowledge of several quality features is needed to be able to determine precisely the real quality of the given wheat. Several systems have been worked out on the qualification of the winter wheat in Hungary and other countries as well. Evaluating the quality is being made more difficult because the different quality features take part in the development of the quality in different degrees and the values of the several quality features are in different intervals and these data are different dimension values. On the evidence of the results, in the case of considering several features, it can be difficult to rank into one concrete quality cathegory. Researchers are trying to develop complex quality index numbers in order to be able to define the quality more precisely. One of these complex quality index numbers is Györi's, so called, Z-index.

In three years from 2006 and 2008, we examined the change of the quality features of nine varieties of winter wheat with the help of the Z-index under the influence of the effects of the different cropyears and the fertilizer treatment. The results show that the Z-index of the examined varieties of winter wheat were influenced by several factors. Examining the data of the three different breeding years together we can observe the corrective effect of the different cropyears on the Z-index, and if we examine the three years separately and together, the differences of the quality features of the different varieties differentiate very well, and with the help of the Z-index the comparison of the types is easier and perspicuous, and the Z-index represents the different nutrient reactions of the different types as well. On the average of the three years, the types gave the best results at $N_{120-150}+P K$ nutrient level. Among the nine varieties the best results were given by Mv Suba, GK Békés and Mv Mazurka in the case of both low and higher nutrient levels.
\end{abstract}

\section{Introduction}

The baking quality of wheat is a complex concept, which, after all, includes the totality of wheat-features which make the production of good quality bakery products from wheat flour possible (Lásztity,1981). Quality does not mean the same for the grower, the corn trader, the milling industry, the baking industry and the customer. After all, quality means the suitability of the important features for the user (Bedö et al.,1997). We can give the quality of winter wheat -according to the consuming demands- by defining and reporting several quality index numbers together. They can be classified into three big groups, features considering the standard of value, nutritionalfeeding value, technological features and the parameters that are important for the food safety (Györi, 2006). According to Pollhamerné (1967), the total quality of wheat can be given only by detailed methods of inquiry and by emphasising their data. Comparing the quality of the different wheat varities can be difficult because the different countries use their own methods to describe the quality features. According to Györi (2008), defining the quality of winter wheat is very difficult on the basis of several parameters. According to his results, $\mathrm{Z}$ index is suitable for comparing the different types of winter wheat, evaluating the effects of fertilization and analysing the effects of the cropyear. According to Györi and Györiné (1998), quality is influenced by several factors of which complex effects resultant is the composition typical of the given species of plants. These factors were classified into two groups: internal and external factors. Genetic features are primarily important. But the factors which define the quality take part in developing the quality in different rates and among these factors the determinative ones are the quality of the variety and other agronomical features. The success and fullfillment of these genetical features are ensured by environmental factors. The technological interferences and treatments performed during the cropyear and the cultivation of the plants basically influence the milling- and baking quality of wheat.Quality is the genetically determined ability of the variety, which can be enforced and destroyed but develop in no way by agronomical methods. Quality wheat-growing is nothing else but the optimalization of the growing factors according to quality indexes (Jolánkai e al., 2004). According to Vida and Jolánkai's (1995) researches the bad quality varieties could not produce good quality even under favourable agronomical conditions. The baking quality was highly influenced by the applied fertilizer. On the average of the years, water supply and the varieties, by increasing the quantity of the fertilizer, the gluten-content, the farinographic water absorbing capacity and farniographic value increased too. According to Tanács et al., (2006), the effects of the varieties and the years are decisive at the wet gluten-content and baking values. Accordig to Geleta et al.,(2002), the agronomical performance and the quality features of the winter wheat are highly influenced by the environmental factors. 


\section{Material and Method}

The experiments were carried out at the Látókép Research Site of the University of Debrecen. This research site is situated $15 \mathrm{kms}$ west from Debrecen, on the loess ridge of the Hajdúság region. The soil of the research area is calcerous chernozem of clay cathegory, its $\mathrm{pH}$ is neutral and has medium humus-content. The small scale experiment was set up in autumn 1983. We examined the results of the years 2006-2008. The short term, smallscale experiment was set in a split-split-spot desing in four repetitions. The nutrient reactions of 15 winter wheat varieties were examined. The precrop was sweetcorn in the experiment. Six nutrient levels were adopted in the treatments.

Beside the control treatment $\mathrm{N}=30 \mathrm{~kg} \mathrm{ha}^{-1}, \mathrm{P}_{2} \mathrm{O}_{5}=22,5 \mathrm{~kg} \mathrm{ha}^{-1}$ and $\mathrm{K}_{2} \mathrm{O}=26,5 \mathrm{~kg} \mathrm{ha}^{-1}$ ha amount of basic fertilizer and double, triple, fourfold and fivehold of it were applied. $\mathrm{P}$ and $\mathrm{K}$ fertilizer doses in $100 \%$ in autumn and $\mathrm{N}$ fertilizer doses in $50-50 \%$ in spring and autumn were applied. The fertilizer doses applied at different nutrient levels are shown in Table 1.

Table 1

Table 1: Applied fertilizer doses

(Debrecen, 2006-2008)

\begin{tabular}{|c||c|c|c|}
\hline \multirow{2}{*}{ Treatment } & $\mathrm{N}$ & $\mathrm{P}_{2} \mathrm{O}_{5}$ & $\mathrm{~K}_{2} \mathrm{O}$ \\
\cline { 2 - 4 } & \multicolumn{3}{|c|}{$\mathrm{kg} \mathrm{ha}^{-1}$} \\
\hline Control & 0 & 0 & 0 \\
\hline $\mathrm{N} 30+\mathrm{PK}$ & 30 & 22,5 & 26,5 \\
\hline $\mathrm{N} 60+\mathrm{PK}$ & 60 & 45 & 53 \\
\hline $\mathrm{N} 90+\mathrm{PK}$ & 90 & 67.5 & 79.5 \\
\hline $\mathrm{N} 120+\mathrm{PK}$ & 120 & 90 & 106 \\
\hline $\mathrm{N} 150+\mathrm{PK}$ & 150 & 112.5 & 132.5 \\
\hline
\end{tabular}

The precipitation and the temperature values in the vegetation period in 2006-2008 are shown in Table 2.

Main meteorological data of vegetation period

Table 2 (Debrecen, 2006-2008)

\begin{tabular}{|c|c|c|c|c|c|c|c|c|c|c|c|}
\hline & Oct. & Nov. & Dec. & Jan. & Feb. & Mar. & Apr. & May & Jun. & $\begin{array}{c}\text { Total/ } \\
\text { Average }\end{array}$ & Difference \\
\hline \hline Precipitation $(\mathrm{mm}) 2005$ & 38,9 & 63,5 & 33,7 & 18,2 & 40,6 & 10,5 & 74,9 & 75,8 & 54,3 & 410,4 & 9,5 \\
\hline Precipitation $(\mathrm{mm}) 2006$ & 7 & 12,6 & 83,5 & 22,5 & 44,2 & 79 & 92,3 & 58,3 & 77,1 & 476,5 & 75,6 \\
\hline Precipitation $(\mathrm{mm}) 2007$ & 22,9 & 9,2 & 5 & 23,9 & 53,2 & 14 & 3,6 & 54 & 22,8 & 208,6 & $-192,3$ \\
\hline Precipitation (mm) 2008 & 71,4 & 40,9 & 29,8 & 26,4 & 4,6 & 41,7 & 74,9 & 47,6 & 137,8 & 475,1 & 74,2 \\
\hline 30 year's average & 30,8 & 45,2 & 43,5 & 37 & 30,2 & 33,5 & 42,4 & 58,8 & 79,5 & 400,9 & 0 \\
\hline Temperature $\left({ }^{\circ} \mathrm{C}\right) 2005$ & 11,1 & 4,9 & 0,9 & $-0,9$ & $-3,7$ & 2,2 & 10,8 & 16,2 & 18,4 & 6,7 & $-0,3$ \\
\hline Temperature $\left({ }^{\circ} \mathrm{C}\right) 2006$ & 10,8 & 3,5 & 0,2 & $-3,4$ & $-1,4$ & 3,2 & 12,1 & 15,4 & 18,6 & 6,6 & $-0,4$ \\
\hline Temperature $\left({ }^{\circ} \mathrm{C}\right) 2007$ & 11,3 & 6,2 & 2,2 & 3,7 & 4,1 & 9,1 & 12,6 & 18,4 & 22,2 & 10 & 3 \\
\hline Temperature $\left({ }^{\circ} \mathrm{C}\right) 2008$ & 9,7 & 3,5 & $-0,6$ & 1 & 3 & 6,2 & 11,4 & 16,8 & 20,6 & 8 & 1 \\
\hline 30 year's average & 10,3 & 4,5 & $-0,2$ & $-2,6$ & 0,2 & 5 & 10,7 & 15,8 & 18,8 & 6,94 & 0 \\
\hline
\end{tabular}

The years 2005/2006 proved to be unfavourable considering the autumn and early winter weather and that the spring was coming late, but the amount of rainfall in spring and early summer and the weather was favourable for the winter wheat. The vegetation period in 2006/2007 was characterized by lack of rainfall and drought, which unfavourably affected the growth of winter wheat. In 2007/2008 the autumn, winter and early spring weather was the best, however, the stocks having big vegetative mass were beaten down and the droughty summer disturbed the grain saturation. The quality parameters were determined at the Accredited Instrument Centre of Debrecen University AGTC. (The values were determined according to the following standards: the wet gluten content according to MSZ ISO5531:1993, the valorigraphic value according to MSZ ISO 530:1995, the gluten elasticity according to MSZ ISO 5531:1993, the falling number according to MSZ ISO 3093:1995, the protein-content of the flour according to ICC 159:1995.

The evaluation of the results were carried out with the help of Györi's Z-index system. The method was modified in the respect that we scored the winter wheat varieties according to six quality features. In consequence of the modification, from the originally examined eleven features only six were examined so the attainable highest value was 165 and the lowest was 15 . 


\section{Results and Discussion}

The Z-index values of the examined nine varieties of winter wheat are shown in Table 3 (2006), Table 4 (2007) and Table 5 (2008). These data show that the highest Z-index values of the varieties were obtained in 2006. In this year because of the fertilizer treatments, the biggest increase of Z-index was obtained at GK Öthalom. It achieved only $75 \mathrm{Z}$-index value in the control treatment while in the case of $\mathrm{N}_{150}+\mathrm{PK}$ treatment the Z-index value was 96, which clearly shows this variety's nutrient reaction. In 2006 the other eight examined varieties of winter wheat showed relatively stable quality results. However, a small increase in Z-index value is observable as a result of the increasing nutrient doses, but to a much lesser degree than in the case of GK Öthalom. On the evidence of the Z-index values of the examined wheat varieties they can be divided into two groups. It is observable, that GK Öthalom, GK Kapos, Lupus and Sixtus achieved quite low Z-index value (75101), both in case of increasing nutrient supply and in the control treatment. The values of GK Széphalom, Mv Suba, Saturnus, GK Békés and Mv Mazurka were much higher. The Z-index values of these varieties were about 110-115 under control treatment while at the nutrient level of $\mathrm{N}_{150}+\mathrm{PK}$ they varied between 120-125. This difference between the Z-index values can be attributed to the genetic potential of the varieties and their nutrient utilizing ability. The best results were shown by GK Békés, which gave the best resuls even at the nutrient level of $\mathrm{N}_{30}+\mathrm{PK}$.

Effect of fertilization on the Győri's Z-index values of the examined varieties of winter wheat (Debrecen, 2006)

\begin{tabular}{|c|c|c|c|c|c|c|}
\hline Variety / Fertilization & Control & N30+PK & N60+PK & N90+PK & N120+PK & N150+PK \\
\hline GK Békés & 115 & 125 & 120 & 120 & 125 & 125 \\
\hline GK Kapos & 91 & 91 & 91 & 100 & 101 & 101 \\
\hline GK-Öthalom & 75 & 79 & 89 & 93 & 93 & 96 \\
\hline KG Széphalom & 110 & 110 & 110 & 115 & 110 & 115 \\
\hline Lupus & 96 & 101 & 96 & 96 & 101 & 100 \\
\hline Mv Mazurka & 115 & 120 & 120 & 120 & 120 & 120 \\
\hline Mv Suba & 110 & 120 & 120 & 120 & 120 & 125 \\
\hline Saturnus & 110 & 120 & 120 & 120 & 120 & 120 \\
\hline Sixtus & 96 & 91 & 96 & 96 & 96 & 101 \\
\hline
\end{tabular}

The year 2007 was unfavourable for both the vegetative and the generative development of the winter wheat. There was a decrease in Z-index values compared to the ones in 2006. While in 2006 the lowest Z-index value was 75, in 2007 the value was only 47, and while in 2006 the maximum value was between 120-125, in 2007 it was only between 110-115 even in the case of the varieties that give the best quality. In 2007 the nutrient reaction of the types can be observed better on the basis of their Z-index values. The increase of Z-index value was on higher degree as a result of the increasing fertelizer doses, and in that year the types showed less stable Z-index values. The types can be divided into two large groups according to their Z-index values. GK Kapos, GK Öthalom, Lupus and Sixtus gave lower Z-index values so lower quality again in the case of their control treatment (49-61) and bigger nutrient doses (62-96). GK Békés, Saturnus, Széphalom, Mv Mazurka and Mv Suba achieved much higher values in every nutrient treatment. These types gave much stable, less increasing Zindex values as a result of their better genetic basis and better nutrient reaction. In 2007 the best results at control (110) and lower levels were given by Mv Suba while at higher levels by GK Békés type.

Effect of fertilization on the Győri's Z-index values of the examined varieties of winter wheat (Debrecen, 2007)

\begin{tabular}{|c||c|c|c|c|c|c|}
\hline Variety / Fertilization & Control & N30+PK & N60+PK & N90+PK & N120+PK & N150+PK \\
\hline GK-Békés & 69 & 96 & 105 & 105 & 106 & 115 \\
\hline GK-Kapos & 49 & 49 & 92 & 92 & 88 & 96 \\
\hline GK-Öthalom & 57 & 47 & 60 & 57 & 62 & 65 \\
\hline KG-Széphalom & 96 & 98 & 101 & 101 & 106 & 111 \\
\hline Lupus & 60 & 78 & 73 & 83 & 87 & 96 \\
\hline MV-Mazurka & 96 & 96 & 106 & 115 & 111 & 115 \\
\hline MV-Suba & 110 & 105 & 110 & 110 & 101 & 105 \\
\hline Saturnus & 91 & 96 & 101 & 101 & 106 & 106 \\
\hline Sixtus & 61 & 83 & 96 & 101 & 93 & 93 \\
\hline
\end{tabular}


The vegatation period of 2008 crop was favourable for the growth of the winter wheat, the varieties with better nutrient reaction were beaten down due to the effect of bigger fertilizer doses and because of this the quality of the winter wheat was considerably destroyed so we got lower Z-index values. In 2008 the tendency which had been experienced in the previous two years was not observed. In the previous years, the varieties which had given outstandingly good quality at control and higher nutrient dose levels, in 2008 gave the best Z-index values at nutrient levels $\mathrm{N}_{60-90}+\mathrm{PK}$ but because of being beaten down at higher nutrition levels they showed declining or stagnating Z-index values. On $\mathrm{N}_{60-90}+\mathrm{PK}$ nutrient levels Mv Mazurka (110-115) and GK Békés (100-115) proved to be the best in that year, too. At higher nutrient levels $\left(\mathrm{N}_{120-150}+\mathrm{PK}\right)$, the varieties having weaker nutrient reaction were beaten down less or not at all, thus, they showed better Z-index values.

In 2008 we found that by increasing the nutrient doses the Z-index value showed increasing tendency in the case of most varieties. However, in case of certain varieties such as Mv Suba and GK Békés (100-105), at the $\mathrm{N}_{120-150}+\mathrm{PK}$ nutrient level the Z-index values were among the lowest. We found that because of being beaten down the quality decreased and it is clearly represented in Z-index values.

Effect of fertilization on the Győri's Z-index values of the examined varieties of winter wheat

Table 5 (Debrecen, 2008)

\begin{tabular}{|c||c|c|c|c|c|c|}
\hline Variety / Fertilization & Control & N30+PK & N60+PK & N90+PK & N120+PK & N150+PK \\
\hline GK Békés & 90 & 115 & 115 & 100 & 110 & 100 \\
\hline GK Kapos & 54 & 73 & 100 & 96 & 91 & 100 \\
\hline GK-Öthalom & 50 & 83 & 88 & 88 & 96 & 101 \\
\hline KG Széphalom & 64 & 96 & 96 & 106 & 106 & 101 \\
\hline Lupus & 50 & 74 & 101 & 106 & 106 & 106 \\
\hline MV Mazurka & 83 & 105 & 110 & 115 & 105 & 105 \\
\hline MV Suba & 78 & 92 & 100 & 100 & 92 & 105 \\
\hline Saturnus & 54 & 96 & 105 & 105 & 110 & 105 \\
\hline Sixtus & 42 & 88 & 96 & 96 & 96 & 101 \\
\hline
\end{tabular}

Not intending to be exhaustive we try to demonstrate the partial values of Z-index on the examles of two varieties, namely GK Öthalom, which gave poorer quality (Figure 1) and GK Békés, which gave better quality (Figure 2).

Effect of fertilization on the Győri's Z-index values of the examined variety of GK Öthalom

Figure 1 (Debrecen 2006-2008)
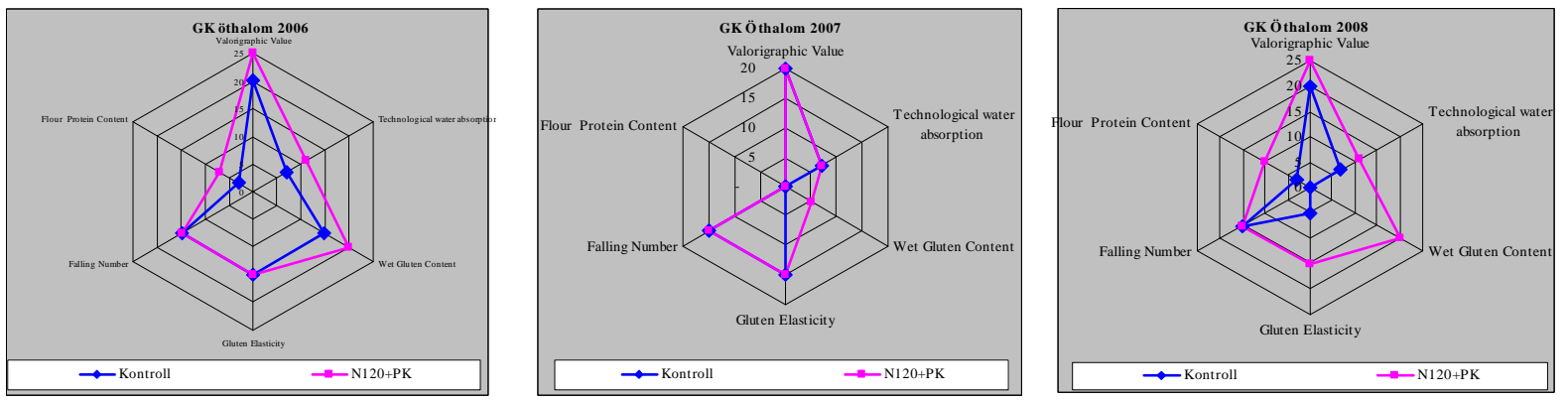

The diagrams show that in the case of GK Öthalom in an average cropyear (2006) as a reault of the increased nutrient dose the protein qualities (protein content of flour, wet gluten content, water absorbing capacity, valiographic value) increased too. In the unfavourable year of 2007 , the increasing nutrient doses did not increased the quality features except from the wet gluten content. In the favourable year of 2008, all other quality parameters increased, except from the falling number. As regards GK Békés, in the average year of 2006 only the wet gluten content increased at $\mathrm{N}_{120}+\mathrm{PK}$ nutrient level compared to the conrol treatment. GK Békés gave good quality even at low nutrient levels, therefore the increase in quality was quite small. In the unfavourable cropyear of 2007 due to the effect of higher nutrient doses there was an increase in wet gluten content, protein content of flour, gluten elasticity, which means that the optimal nutrient supply was able to compensate the unfavourable environmental conditions. 
Effect of fertilization on the Győri's Z-index values of the examined variety of GK Békés (Debrecen 2006-2008)
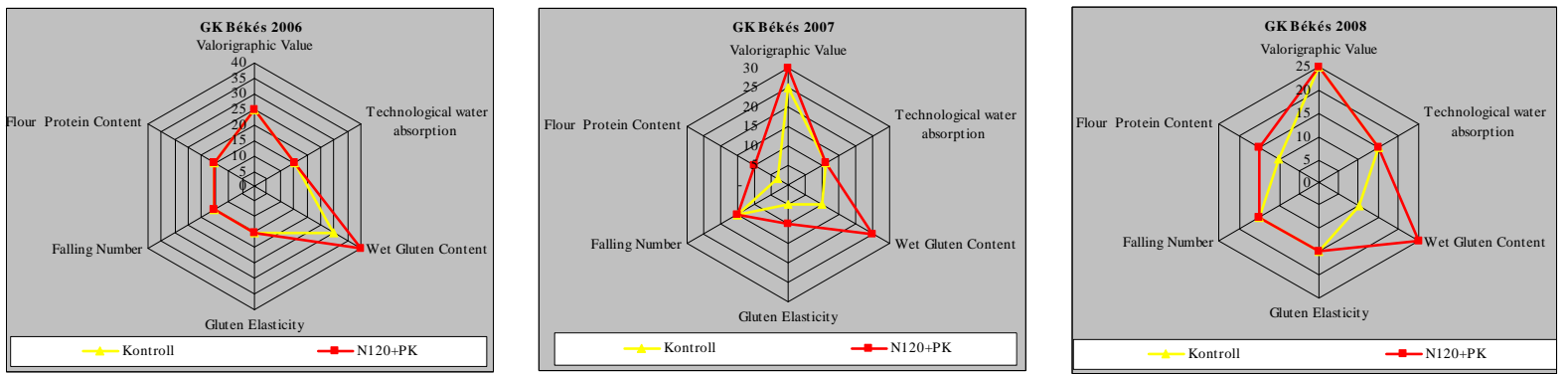

In the optimal year of 2008 the protein content of flour and the wet gluten-content increased at the $\mathrm{N}_{120}+\mathrm{PK}$ nutrient level. The partial values of the Z-index clearly illustrate the change in the quality of the varieties caused by the effect of the nutrient treatments and the cropyear. Z-index values also represent the differences between the varieties.

\section{Conclusion}

The results of our experiment show that several factors influenced the Györi's $Z$ index values of the examined winter wheat varieties. The effect of the cropyear is striking. In the avegage vegetation period of 2006 the quality parameters of the winter wheat varieties were influenced mainly by the genotypes and the nutrient doses. The difference between the quality of the varieties in the cropyear as a result of the nutrient treatment and the different nutrient-utilizing ability of the types is clearly represented by the Z-index values. Certain types, such as Mv Suba, GK Békés and Saturnus produced, even at the control and low fertilizer levels better qualities and better Z-index values than those which give weaker quality even at the optimum or at the highest fertilizer level on the basis of their lower biological ability (GK Öthalom, Lupus). In 2006 the optimum fertilizer dose was $\mathrm{N}_{90-120}+\mathrm{PK}$. On the other hand, in the unfavourable crop year of 2007 the effect of the cropyear is clearly reflected in the $\mathrm{Z}$-index values. The varieties of both the better and the lower quality produced declining $\mathrm{Z}$ index values. This decline could be compensated by the higher amounts of fertilizer doses, however, the highest Z-index values achieved by the varieties were still lower than in 2006 . The optimal nutrient levels were at $\mathrm{N}_{120-150}+\mathrm{PK}$. Although the year of 2008 was optimal, at higher nutrient levels the cultures were beaten down, as a result the quality decreased. The tendency of 2006 and 2007 was not observed in that year, in the case of certain varieties there was a decline in the Z-index at higher nutrient levels. The optimal fertilizer dose was at $\mathrm{N}_{60-90}+\mathrm{PK}$. Examining the data of the three vegetation periods together, we can point out that the Z-index values well reflect the modifying effect of the crop years. Examinig the three crop years separately and together, the differences in the qualities of the varities are clearly represented. With the help of the Z-index the varieties ae easier to be compared, furthermore, the Z-index value represents the different nutrient reactions of the varieties as well. The best results were given by Mv Suba, GK Békés and Mv Mazurka out of the nine varieties both at the lower and the higher nutrient levels.

\section{References}

Bedő, Z. - Láng, L. - Vida, GY. - Juhász, A. - Karsai, I. (1997): A minőségi tulajdonságok felértékelődése a búzanemesítésben. Agro-21 Füzetek. 23. 19-30.

Geleta, B. -Atak, M. -Baenziger, P.S. -Nelson, L.A. -Baltenesperger, D.D. -Eskridge, K.M. -Shipman, M.J. -Shelton, D.R.(2002): Seeding rate and genotype effect on agronomic performance and end-use quality of winter wheat. Crop science. 42/3 827-832.

Györi Z. (2008):Complex evaluation of the quality of winter wheat varieties. Cereal Research Communications 36.5, 1907-1910.

Győri, Z. - Győriné, Mile, I. (1998): A búza minősége és minősítése. Mezőgazdasági Szaktudás Kiadó, Budapest.

Győri, Z. (2006a): Ismét napirenden az őszi búza minősége. Gyakorlati Agrofórum. 7. 27-28.

Jolánkai M.- Szőllősi G.- Szentpétery Zs. (2004): Az őszi búza termesztésnek és minőségének változása különböző évjáratokban. Gyakorlati Agrofórum Extra 6. 6-9

Lásztity, R. (1981): Gabonafehérjék. Mezőgazdasági Kiadó, Budapest.

Pollhamer, E.-né. (1967): The complex qualitative index of wheat. Acta Agronomica Academiae Scient. Hung.16.339-344.

Tanács L.-Véha A.- Petróczi I. (1994): Műtrágyával és fungiciddel kezelt aestivum búzák nedvessikér-tartalom, valorigráfos és alveográfos vizsgálatai az évjáratok függvényében. Növénytermelés, 55. 5-6. 335-355.

Vida, Gy. - Jolánkai, M. (1995): Eltérő sütőipari minőségü búzafajták vizsgálata különböző évjáratok és termesztési tényezők között. Növénytermelés. 44. 1. 43-54. 